\title{
JUDICIAL REVIEW AND JUDICIAL ACTIVISM IN JAPAN
}

\author{
Hiroshi ITOH*
}

\section{Introduction: Judicial Activism Defined}

Judicial activism and judicial restraint describe the relationship between the judiciary and the political branches of government. In the context of Japan, they refer to the relationship between the Supreme Court and inferior courts, on the one hand, and the Diet, the Cabinet, the bureaucracy, and the analogous policymakers of prefectural and local governments, on the other. Judicial activism and restraint have been defined in more than one way. One such definition is that a court exhibits activism when it exercises the power of judicial review regardless of whether it declares a governmental action constitutional or unconstitutional. In this study, however, judicial activism is defined in terms of conflict between the courts and the political branches on constitutional policies. ${ }^{1}$ A court is activist whenever it declares public policies unconstitutional. Conversely, a court is self-restrained whenever it upholds the constitutionality of public policies.

The Meiji Constitution of 1889 did not provide for the power of judicial review. Moreover, it did not recognize the judiciary as independent from the Diet and the Cabinet. As part of the executive branch, the judiciary was not empowered to examine the constitutionality of actions of the Diet or the Cabinet. Furthermore, an administrative court, separate from the ordinary courts of law, maintained exclusive jurisdiction over any administrative disputes. Since this administrative court, the privy council, was for all practical purposes dysfunctional in reviewing whatever constitutional disputes might have been raised, there was no institution that effectively checked the legality or constitutionality of governmental policies and actions.

Judicial review has been firmly established since 1947. The administrative court, the privy council, and all other forms of special tribunals have been abolished. The judiciary, headed by the Supreme Court, now has the final say as to what the law is in any legal dispute. With the power of judicial review and the working principle of stare decisis, the courts have come to make case law and to delineate through litigants the constitutional boundaries of each branch of the national and local governments.

Copyright $\odot 1990$ by Law and Contemporary Problems

- Professor, Department of Political Science, State University of New York, Plattsburgh.

1. G. Schubert, Judicial Policy Making: The Political Role of the Courts 131-35 (1965). 
The Japanese judiciary presently consists of one Supreme Court, eight high courts with six branch high courts, fifty district courts with 242 branch district courts, fifty family courts with 242 branch family courts, and 575 summary courts. Local offices of family courts are also placed at the seats of ninety-six summary courts in some remote areas. ${ }^{2}$ These courts are hierarchically structured, with the Supreme Court at the top and the summary courts at the bottom of the judicial pyramid. The number of judges on the bench ranges from one at the summary court, family court, and district court, to three at the high court, and to fifteen at the Supreme Court. Judicial decisions in a collegiate court are made by simple majority vote with each judge casting one vote. Judicial review at the Supreme Court takes place either in a fifteen-member grand bench or in one of the three five-member petty benches.

The judiciary is hierarchically structured to serve two objectives: first, to provide avenues of three-tiered appeals (the district court, the high court, the Supreme Court) and, second, to provide uniform interpretation of rules of law throughout the courts at all levels. The second objective is to be attained by the use of stare decisis, which recognizes the precedential value of court decisions in similar cases. Influenced by the civil law tradition of Germany, prewar Japan did not have this concept. Yet, with the introduction of judicial review in the 1947 Constitution, stare decisis has become a working doctrine that all judges and courts now put into practice. Precedents established by the Supreme Court bind the judicial decisionmaking of all lower courts in most instances. If a lower court disregards decisions of the Supreme Court, its decision is likely to be reversed upon appeal. Nonetheless, from time to time some lower court judges reach decisions different from Supreme Court precedents and in the long run obligate the highest tribunal to change its precedents.

II

\section{Judicial Activism of Lower Courts}

As defined earlier, judicial activism manifests itself when a court declares acts or actions of the political branches and the bureaucracy unconstitutional and invalid, resulting in a conflict between a court and a policymaker or policy adıninistrator. Judicial activism arises in three different situations: first, when a new policy conflicts with existing precedent; second, when changing precedent conflicts with existing policy; and, third, when both policy and precedent evolve in different directions and at different paces.

First, a conflict emerges when a policymaker undertakes a policy change while a court adheres to an existing judicial precedent and finds the policy change unconstitutional. Such was the case in Sato v. Japan ${ }^{3}$ (the legislative inaction case). In 1952 the Diet abolished absentee voting for physically

2. H. Itoh, The Japanese Supreme Court: Constitutional Policies 30 (1989).

3. 888 Hanrei Jihō 27 (Sapporo H. Ct., May 24, 1978). 
handicapped persons, as the system had allegedly been abused and needed to be reformed. Consequently, severely handicapped persons had to go to a polling station or not vote at all. In reality, over one million handicapped voters lost the right to vote in public office elections. The plaintiff, one of the victims of the change, filed a suit against the state for damages under the State Compensation Code. The Sapporo District Court, Otsu Branch, found for the plaintiff and ruled the abolition of the absentee voting system unconstitutional as a deprivation of the constitutional right to vote. The court was of the opinion that the Diet had exceeded the limits of its legislative discretion and also neglected to provide the plaintiff and other handicapped voters with any alternative method of voting. In short, the district court, adhering to precedent, rejected the legislature's policy change as unconstitutional, in a display of the first type of judicial activism.

This first type of judicial activism also appeared in 1961 when the Ministry of Education, which is part of the national bureaucracy under the Cabinet, introduced a nationwide standardized proficiency test to be administered to all eighth and ninth graders by all local school boards. This administrative change in educational policy met strong opposition from the militant Japan Teachers Union, which had long advocated greater local control over education. Seven defendants in Japan v. Ogawa ${ }^{4}$ (the Iwata Prefecture proficiency test case), were opposed to the proposed test and tried to prevent it from being administered. They issued directives to all union members in Iwata Prefecture to take the day off or to conduct classes as usual during the time planned for the test. One of the defendants also blocked off the road near a junior high school in order to keep test officials from reaching the school. The Morioka District Court found the defendants guilty of violating the Local Public Employees Code and the Road Traffic Code. The Sendai High Court acquitted them, however, by relying upon the Supreme Court decision in the Tokyo Central Post Office case. ${ }^{5}$ According to the high court, punishment of local public employees, such as teachers, is imposed only upon activities of a strong antisocial nature, but the Local Public Employees Code provides penalties for planning, conspiring to effect, instigating, or inciting prohibited disputes. For these reasons, the court ruled that the activities of the defendants did not amount to a crime under the Local Public Employees Code and that the alleged violation of the Road Traffic Code was justifiable as part of a labor dispute under the Labor Union Code. Thus the high court disagreed with the public prosecutor's office as well as with the Minister of Education, who had initiated the change in the nation's educational policy.

In a similar case, the Tokyo District Court acquitted executive members of the All Agriculture and Forestry Workers' Union, composed of public employees of the Ministry who had been charged with violating the National Public Employees Code, which prohibits labor disputes for political

4. 30 Keishū 1179 (Sup. Ct., G.B., May 21, 1976) (rev'g 762 Hanrei Jihō 8 (Sendai H. Ct., Dec. 9, 1974)).

5. Toyama v. Japan, 20 Keishū 901 (Sup. Ct., G.B., Oct. 26, 1966). 
purposes. ${ }^{6}$ In 1958, the defendants persuaded and instigated their union members to participate in a workplace rally against proposed legislative changes designed to strengthen the police power. Thus, the district court became activist in relation to the Diet and the Cabinet.

A second type of judicial activism emerges when a court changes its judicial precedent and declares existing public policies unconstitutional. Here the court becomes a driving force behind a new social policy even though there has been no policy change on the side of the political branches. Some people might view this activism as undesirable judicial superlegislation.

Fukuoka Prosecutors' Office v. Yamato ${ }^{7}$ (the patricide case) illustrates this type of judicial activism. In the patricide case, the Supreme Court upheld the constitutionality of Article 205 of the Criminal Code that imposed either capital punishment or life imprisonment on those guilty of causing the death of lineal ascendants. Yet, in Japan v. Aizawa, ${ }^{8}$ the Utsunomiya District Court challenged the Supreme Court precedent of 1950 and declared Article 200 of the Criminal Code an unconstitutional violation of the equality clause of the Constitution. ${ }^{9}$ The district court was of the opinion that Article 200 unreasonably discriminated against lineal descendants by adhering to Confucian ethics, which stress the socially harmful and unethical nature of killing a lineal ascendant. Thus, the district court dared to set itself apart from Supreme Court precedent and declare the provision of the Criminal Code unconstitutional.

Finally, a third type of judicial activism manifests itself when both a policymaker and a court change their respective policies in different directions and/or at different paces. In either case, a court with a new judicial policy will find a new legislative or executive policy unconstitutional, thereby creating a conflict with the political branch. The well-known and controversial decision in the Naganuma Nike missile case ${ }^{10}$ offers a good example of this type of judicial activism. In that case, a large number of farmers filed a suit when the government decided to build a Nike missile base within a nearby forest reserve without holding a public hearing as required under the Forest Code. Issuing an injunction against the government decision to build the base, the Sapporo District Court upheld the farmers' contentions. In the opinion of the court, the farmers benefitted directly from the preservation of the forest reserve, which served as a cow pasture for the local dairy business and aided flood prevention. Therefore, the farmers, as beneficiaries of forest use, had legal standing to sue. The proposed missile base would be unconstitutional

6. Tsuruzono v. Japan (The All Agriculture and Forestry Workers' Union Case), 27 Keishū 547 (Sup. Ct., G.B., Apr. 23, 1973).

7. 4 Keishū 2037 (Sup. Ct., G.B., Oct. 11, 1950) (rev'g 4 Keishū 2070 (Fukuoka Dist. Ct., lizuka Br., Jan. 9, 1950)).

8. Aizawa v. Japan, 27 Keishū 265 (Sup. Ct., G.B., Apr. 4, 1973) (aff'g l Keisai Geppō 544 (Utsunomiya Dist. Ct., May 29, 1969) and rev'g 619 Hanrei Jihō 93 (Tokyo H. Ct., May 12, 1970)).

9. 1947 Const. art. 14.

10. 36 Minshū 1679 (Sup. Ct., Ist P.B., Sept. 9, 1982) (rev'g 712 Hanrei Jihō 24 (Sapporo Dist. Ct., Sept. 7, 1973) and aff'g 27 Gyōhan 1175 (Sapporo H. Ct., Aug. 5, 1976)). 
as a violation of the no-war clause of the Constitution." In ruling the base unconstitutional, the district court directly challenged the Supreme Court precedent established in 1959 in the Sunakawa case, ${ }^{12}$ which upheld the constitutionality of the Self-Defense Forces, the U.S. Mutual Security Treaty, and American military bases in Japan. The unequivocal deviation from the Sunakawa ruling made the district court pronouncement controversial.

Judicial power is exercised to settle disputes between litigants. It is exercised by the judiciary with certain limitations. Actual and concrete disputes must exist before the court can adjudicate. No declaratory or advisory opinions are allowed in Japan. There are also nonjusticiable types of disputes involving state governance or the political branches of government. Furthermore, Justice Brandeis' guidelines ${ }^{13}$ for invoking judicial review have been modus operandi in Japan. In this light, many constitutional scholars have praised the boldness and candidness of the Sapporo district court ruling in the Naganuma Nike missile case.

So far we have examined the typology of judicial activism exhibited by lower courts in Japan. Since there are a relatively large number of lower courts, governmental policies and decisions are challenged by some lower courts rather regularly. Yet, on appeal, judicial decisions holding governmental policies unconstitutional are often reversed. That is, lower court judicial activism is reversed to judicial restraint when a court of appeals sustains the constitutionality of public policies and restores harmony with the political branches. In the legislative inaction case, ${ }^{14}$ the Sapporo High Court held that although the failure of the Diet to reinstate the absentee system between 1969 and 1972 was unconstitutional, the plaintiff could not establish the necessary intentional or negligent infliction of injury by the Diet to succeed in an action for damages under the State Compensation Code. This decision allowed legislative inaction to remain outside effective judicial control. Conversely, a district court may remain restrained in relation to a governmental policy, but upon appeal a high court may reverse the district court decision, demonstrating judicial activism.

However, what is most important is judicial review by the Supreme Court as the court of last resort. In a large majority of instances, the Supreme Court has sustained lower court decisions. But, in some cases, especially important constitutional cases, the Supreme Court has reversed the judicial activism of lower courts. In fact, except for the Aizawa patricide case, ${ }^{15}$ all of the activist decisions of lower courts cited in this study have, upon appeal, been reversed by the Supreme Court.

In the Iwata Prefecture proficiency test case, ${ }^{16}$ the Court restored harmony with the government by reversing the activist lower court decision. In the

\footnotetext{
11. 1947 Const. art. 9.

12. Sakata v. Japan, 13 Keishū 3225 (Sup. Ct., G.B., Dec. 16, 1959).

13. Ashwander v. T.V.A., 297 U.S. 288, 346-56 (1936).

14. 888 Hanrei Jihō 27.

15. 27 Keishū 265.

16. 30 Keishū 1179 .
} 
opinion of the Court, the disputes at issue did not fall within the bounds of the worker's right to engage in disputes, because the objective of preventing the implementation of the proficiency test had no direct relationship to improving the financial or working conditions of teachers, but rather may be regarded as a political objective in opposition to the educational policies of the Ministry of Education. The Supreme Court also held the activities of the defendants to constitute a crime under the Local Public Employees Code. Likewise, in the All Agricultural and Forestry Workers' Union case, ${ }^{17}$ the Court convicted the defendants and stated that their activities encouraged disputes as proscribed by the National Public Service Code.

It is widely asserted that the Supreme Court is so judicially restrained toward the conservative government led by the Liberal Democratic Party ("LDP") that it discourages some reform-minded, progressive lower court judges from deciding against the government in civil liberties and civil rights cases. While there is some merit in this assertion, there is no empirical verification of it. ${ }^{18}$

Especially where constitutional rights of the criminally accused are involved, the Supreme Court has ruled unconstitutional and invalid governmental decisions and practices, while lower courts remain nonactivist on the same issues. Where a trial was suspended for fifteen years, for instance, the Supreme Court, and not the lower courts, agreed with the defendant's argument that such a delay, which was not caused by the defense, violated the defendant's constitutional right to receive a speedy trial. ${ }^{19}$ Likewise, the Supreme Court, and not the lower courts, became activist, as will be elaborated shortly, in a case where a local government tried to limit the number of pharmaceutical stores in a geographical area.

In summary, it cannot be concluded that lower courts are more judicially activist than the Supreme Court in relation to the political branches and the bureaucracy. Some people argue that lower court judges, who are relatively young, tend to be more activist than Supreme Court justices, who are considerably older. Age, however, does not seem to be a determining factor of judicial activism. Still other critics argue that Supreme Court justices were educated and trained, and even practiced law, under the prewar legal system and are sympathetic to the conservative government's ideologies and policies, while lower court judges have been mostly educated and trained under the new constitutional spirit, which often sets them apart from the conservative government and its policies. Yet, there does not seem to be any meaningful correlation between the legal education and socialization of judges, on the one hand, and judicial activism on the other. Overall, the Supreme Court and the lower courts more often than not agree rather than disagree on constitutional policies, and their agreements tend to render them judicially nonactivist vis-á-vis the political branches.

17. 27 Keishū 547.

18. See Н. Ітон, supra note 2, at 274-76.

19. Park v. Japan, 26 Keishū 631 (Sup. Ct., G.B., Dec. 20, 1972). 


\section{III}

\section{Judicial Activism of the Supreme Court}

The first type of judicial activism was affected by a policy change on the side of a political branch. In 1964, the Diet amended the Pharmaceutical Code to give a prefectural governor the authority to deny any new application for a license to open a drugstore if the proposed site for the new store would be too close to existing stores. When the plaintiff was denied a license, the Supreme Court unanimously ruled $^{20}$ that both the amendment to the Pharmaceutical Code and the Hiroshima Prefectural Ordinance enacted to administer the Code violated the constitutional guarantee of the freedom of occupation, since the governor failed to demonstrate any evidence of a widespread practice of dispensing substandard drugs due to excessive competition among drugstores in some locations. It is interesting to note that the amendment to the Code was a direct result of strong lobbying activities by the owners of existing stores to limit the opening of new stores that would cut into their economic profits.

The second type of judicial activism resulting from a new judicial policy is best illustrated by the patricide case. In 1950, the Supreme Court sustained the constitutionality of Article 205 of the Criminal Code, which imposed much heavier penalties upon patricide than other forms of manslaughter. ${ }^{21}$ In 1973, however, the Court, composed of different justices, agreed with the Utsunomiya District Court, which held that the criminal provision on patricide is unreasonably harsh and exceeds the limit necessary to achieve legislative objectives that can be better served by applying Article 199 to the manslaughter of lineal ascendants. ${ }^{22}$ The present Criminal Code was adopted before World War II, and much of it was revised in 1947 to realize the fundamental human rights embodied in the 1947 Constitution. But Article 200 was not touched then or later. In the absence of legislative change in the Criminal Code on patricide, the Supreme Court changed its judicial precedent and conflicted with the Diet, which has not yet reconciled the patricide provision with the equality clause of the Constitution.

A variation on the second type of judicial activism is discernible when the Supreme Court declares unconstitutional an existing public policy. With the adoption of the new Constitution in 1947, the Diet revised, amended, or added to public policies that had been legislated under the Meiji Constitution, to accord better with the spirit of the new legal order. Yet some of these policies were not challenged in a lawsuit until much later. When they were finally challenged, they were declared unconstitutional. One such instance is the Supreme Court decision on the Forest Code in 1987.23 The Forest Code prohibits a co-owner or co-owners whose share is singly or jointly less than

20. Umehara v. Japan, 29 Minshū 572 (Sup. Ct., G.B., Apr. 30, 1975) (affirming decision of Utsunomiya Dist. Ct.).

21. 4 Keishū 2037.

22. 27 Keishū 265.

23. Hiraguchi v. Hiraguchi, 41 Minshū 408 (Sup. Ct., G.B., Apr. 22, 1987). 
one-half of the value of the community forest from requesting to have his or their communal forest partitioned or subdivided. Its legislative intent is to prevent community property from being divided, which would harm conservation of the forest. The Supreme Court nonetheless ruled that this provision would deprive co-owners of their constitutional rights to property.

The third type of judicial activism emerges when both the policymakers and the Court change their respective policies and when such changes are in opposite directions and/or at different paces. The Kurokawa malapportionment case ${ }^{24}$ demonstrated the judicial activism of the Supreme Court in 1976 when both the Diet and the Court made changes in the same direction but at different rates. In 1964, the Supreme Court, by dismissing a voter's charge of malapportionment in the election of the House of Councillors, reasoned that apportionment in a national election is left to the discretionary power of the Diet and that only in the case of extreme inequality in voting can a court declare the election invalid. ${ }^{25}$ Thereupon, the Diet initiated a partial reapportionment in some of the most underrepresented metropolitan areas. Yet in 1976 the Court declared an election unconstitutional in violation of the one-man, one-vote principle. The chain of events surrounding the 1964 decision, the subsequent policy change by the Diet, and the 1976 decision reversing the 1964 precedent suggest that the Diet and the Court made policy changes in the direction of correcting malapportionment, but at different paces.

\section{IV}

\section{The Nature and Prospect of Judicial Activism}

The political branches have shown a measure of sensitivity whenever the Supreme Court has declared their policies unconstitutional. Following the Supreme Court decisions in the Pharmaceutical Code case, ${ }^{26}$ the confiscation of the third party's property case, ${ }^{27}$ the Agricultural Land Code case, ${ }^{28}$ and the Forest Code case, ${ }^{29}$ the Diet quickly removed the unconstitutional portions of each legislation and restored harmony with the Supreme Court. Only in the patricide and malapportionment cases has the Diet not revised, respectively, Article 200 or 205 of the Criminal Code or the apportionment schedules in the Public Officials Election Act.

Judicial culture throughout the Tokugawa feudal period and the Meiji oligarchy instilled judicial restraint in the Japanese body politic. Judicial restraint persists among judges who view it as their primary function to settle legal disputes within the narrow confines of the law provided by legislators

24. Kurokawa v. Chiba Prefecture Election Commission, 30 Minshū 223 (Sup. Ct., G.B., Apr. 14, 1976)

25. Koshiyama v. Tokyo Metropolitan Election Commission, 18 Minshü 270 (Sup. Ct., G.B., Feb. 5, 1964).

26. 29 Minshū 572.

27. Nakamura v. Japan, 16 Keishū 1593 (Sup. Ct., G.B., Nov. 28, 1962).

28. Hayashi v. Governor, Aichi Prefecture, 25 Minshū 1 (Sup. Ct., G.B., Jan. 10, 1971).

29. 26 Keishū 631 . 
and administrators. Even if judges declare the unconstitutionality of public acts and actions, they are most reluctant to suggest policy guidelines to rectify unconstitutional policies. For instance, in the 1976 malapportionment case, ${ }^{30}$ the Supreme Court dismissed the portion of the appeal that sought to nullify the results of the unconstitutionally held election and noted that a judicial nullification of the election result would not correct any error already committed, but would instead disrupt legislative processes. Furthermore, the Court failed to suggest any guidelines regarding the discrepancy in several election districts of the ratio between the voting population and the number of Diet seats apportioned, and the discrepancy that could be tolerated without violating the equality of voting rights.

Policymaking in Japan is often dominated by the ruling LDP (which is really a conservative party), by the national bureaucrats, and by the lobbyists of large corporations. Such policymaking is generally referred to as triumvirate decisionmaking. Of the three groups, superbureaucrats are in control of the actual legislative processes. They have both expertise and experience in policymaking. Since the LDP has been in power over thirty-five years, bureaucrats are quite familiar with the policy ideas and preferences of the conservative ruling party. Judges are another type of bureaucrat in that they are career judges from day one after their graduation from the Judicial Research and Training Institute until their retirement. On the other hand, judges overall are highly capable and independent thinkers; they are not trained or expected to think like normal politicians or bureaucrats.

The legislative process engages policymakers who are expected to pursue power, prestige, and personal interests. The bureaucratic process is characterized by simple rulemaking that takes into account support and feedback from the people. Many judges are reluctant, if not incompetent, to dispose of a legal dispute concerning the propriety of specific social or public policies. They would rather leave policy decisions to politicians and bureaucrats. Only when the unconstitutionality of public policy becomes so obvious, or administrative discretion becomes so unreasonable and arbitrary, would the judiciary dare to declare the governmental actions null and void. So far the Supreme Court has declared only a half-dozen acts of national legislation unconstitutional.

Against this general background, let us speculate briefly about the prospects for each of the three types of judicial activism in the near future. The chance that the Court will follow its own judicial precedent in the face of a policy change by the political branches is very slim. This type of judicial activism is likely to happen when there are slow changes in the composition of the Court and more rapid changes in the composition of the political branches of government. The bureaucrats and the politicians have essentially remained in office under the conservative LDP government for the past thirty-five years, or over forty years if we count the LDP's predecessors. Major policy changes

30. 29 Minshū 572. 
may emerge if opposition political parties, like the Japan Socialist Party ("JSP"), become the majority party in the Diet, either singly or in coalition, and legislate new policies significantly different from those of the LDP while the LDP-appointed Supreme Court adheres to the precedents it created during the LDP government. Due to a very high annual turnover of the justices, even this activism will not last long because the new government will start appointing new justices of its choice. In short, rapid changes in the Supreme Court membership and incremental policy changes in the government will continue to work against the first type of judicial activism.

The chance of the second type of judicial activism emerging is even smaller. The Supreme Court has been extremely reluctant to change its judicial precedents for fear of upsetting the status quo and the predictability of public policymaking. Whenever the Court changed its precedents in the past two decades, it has changed earlier judicial activism to judicial restraint vis-á-vis the political branches. Unless the future Supreme Court is packed by reform-oriented justices, the current judicial restraint is here to stay for a long time. Yet it would be illogical for the LDP to appoint progressive justices who would decide constitutional issues contrary to the party's ideology on national security, public welfare, and civil liberties issues. Should an opposition party like the JSP succeed the LDP government, it will appoint more progressive justices than the LDP. One weakness of this scenario is that such a new government may not be able to overcome the well-fortified judicial bureaucracy of the Supreme Court General Secretariat, which effectively controls judicial appointment. Japanese judges, like their counterparts elsewhere, are basically status quo-oriented and would think twice before changing judicial precedents. At the same time, a variation of the second type of judicial activism is likely to emerge from time to time when the Supreme Court reviews and declares unconstitutional many other provisions of both legislative and administrative laws that were enacted shortly after World War II but that have never been tested in a court of law. It is logical, then, to assume that the likelihood for the third type of judicial activism, where a court becomes a catalyst for social change, is once again very small.

\section{V}

\section{Conclusion}

Japan is a bureaucratic state in which high-ranking administrators shape and reshape many public policies. Courts have been very willing to defer their judgment to that of bureaucrats and politicians on sociopolitical policymaking. Indeed, one of the key reasons for the successful operation of judicial review on Japanese soil is the sparse and cautious invocation of this newly acquired constitutional power, lest the powerful political branches become upset by any appearance of judicial superlegislation. It seems that the Supreme Court's strategies of maintaining a low profile and of judicial restraint toward the legislative and executive branch have paid off to preserve and consolidate the institution of judicial power. Only when the Supreme 
Court perceives that civil liberties and civil rights are at issue has the highest tribunal in Japan been inclined to declare laws and regulations unconstitutional. Of a total of six legislative codes found partially unconstitutional, two violated equality under law, ${ }^{31}$ one contravened due process, ${ }^{32}$ one breached freedom of occupation, ${ }^{33}$ and two transgressed private property rights. ${ }^{34}$ Thus, all six cases involved fundamental human rights, which are better known as civil liberties. Otherwise, Japanese judges do not wish to play an activist role in policymaking. Most constitutional scholars are disappointed by the judicial nonactivism of the Supreme Court. There is also nothing in the Constitution or any other law to prevent judges from assuming a catalyst role in social change; but the judicial and legal culture, social conditions, and the configuration of the governing power in Japan are not conducive to judicial activism. The people of Japan will have to continue to look to the political branches for the realization of the constitutional aspirations of pacifism, popular sovereignty, and even fundamental human rights.

31. Aizawa, 27 Keishū 265; Kurokawa, 30 Minshū 223.

32. Nakamura, 16 Keishū 1593.

33. Kakukichi, 29 Minshū 572.

34. Hayashi, 25 Minshū 1; Hiraguchi, 41 Minshū 408. 
